\title{
Targeting an artificial metal nuclease to DNA by a simple chemical modification and its drastic effect on catalysis
}

\author{
Nathalia Castilho a, Philipe Gabriel a, Tiago Pacheco Camargo ${ }^{b}$, Ademir Neves ${ }^{b *}$ and \\ Hernán Terenzi ${ }^{\text {a* }}$
}

Supplementary Material

\section{EXPERIMENTAL SECTION}

\section{Synthesis of the complex}

All starting materials were purchased from Aldrich, Acros, or Merck. The $N^{6}-($ aminoethyl)adenine (Aead) and 2[(bis(pyridylmethyl)amino)methyl]-4-methyl-6-formylphenol (Hbpmamff) were prepared from methods already described in the literature ${ }^{1,2}$ IR spectra were recorded with a PerkinElmer FTIR Spectrum 100 spectrophotometer $(\mathrm{KBr}$ pellets). Elemental analysis was performed on a Carlo Erba E-1110 analyzer. Electronic absorption spectra in the 200$1200 \mathrm{~nm}$ range were recorded on a PerkinElmer Lambda 750 spectrophotometer. Electrospray ionization mass spectrometry (ESI-MS) of the complexes dissolved in an ultrapure $\mathrm{CH}_{3} \mathrm{CN}$ solution $(500 \mathrm{nM})$ was performed using an AmaZon X Ion Trap MS instrument (Bruker Daltonics) with an ionspray source using electrospray ionization in positive-ion mode. The ion-source voltage was $4500 \mathrm{~V}$. Nitrogen was used as the nebulizing (20 psi) and curtain (10 psi) gases. The samples were directly infused into the mass spectrometer at a flow rate of $180 \mu \mathrm{L} / \mathrm{h}$. The scan range was from $m / z 100$ to 1500 . The simulated spectra were calculated using the Mmass software ${ }^{3}$.

\section{Synthesys of HLPu}

In a $125 \mathrm{~mL}$ round-bottom flask, $0.62 \mathrm{~g}(3.50 \mathrm{mmol})$ of $\mathrm{N} 6$-(aminoethyl) adenine was dissolved in $40 \mathrm{~mL}$ of metanol. In the next step, $30 \mathrm{~mL}$ of a methanol solution containing $1.22 \mathrm{~g}$ of Hbpmamff $(3.50 \mathrm{mmol})$ was added slowly. The mixture was stirred at room temperature for $4 \mathrm{~h}$. Subsequently, the mixture was cooled to $0{ }^{\circ} \mathrm{C}$ in an ice bath, and small portions of $\mathrm{NaBH} 4$ were added directly $(0.13 \mathrm{~g}, 3.50 \mathrm{mmol})$ under constant stirring. The solution was stirred for another $3 \mathrm{~h}$, and it was possible to observe the decrease in the intensity of the yellow color. A 1.0 M HCI solution was then added in small portions to adjust the $\mathrm{pH}$ to 6 , and the solvent was removed by rotary evaporation. To the resultant oil was added $80 \mathrm{~mL}$ of DCM, and the solution was washed with a saturated aqueous solution of NaHCO3 $(3 \times 20 \mathrm{~mL})$. The organic layer was dried with solid anhydrous $\mathrm{Na} 2 \mathrm{SO} 4$, and the solvent was removed under reduced pressure. As a result, $1.21 \mathrm{~g}$ of a yellow sólid was obtained (yield: 68\%). IR (KBr pellets, cm-1): v(O-H) 3430, v(N-H) 3206, v(CHAr) 3043, v(C-HAliph) 2922, 2810, $v(\mathrm{C}=\mathrm{C}) 1593, v(\mathrm{C}=\mathrm{N}) 1535, \delta(\mathrm{O}-\mathrm{H}) 1387, \delta(\mathrm{C}-\mathrm{HAr}) 798, \delta(\mathrm{C}-\mathrm{HAr}) 761.1 \mathrm{H}$ NMR (CDCl3): $\delta$ - $2.18(3 \mathrm{H}, \mathrm{s}), 2.61(2 \mathrm{H}, \mathrm{t}), 3.30(2 \mathrm{H}, \mathrm{t}), 3.66-3.82(4 \mathrm{H}, \mathrm{s}), 4.10(4 \mathrm{H}, \mathrm{s}), 5.39(1 \mathrm{H}, \mathrm{s}), 6.92(2 \mathrm{H}$, s), 7.21-7.37 (4 H, m), $7.69(2 \mathrm{H}, \mathrm{t}), 8.15(1 \mathrm{H}, \mathrm{s}), 8.52(2 \mathrm{H}, \mathrm{s}), 11.29(1 \mathrm{H}, \mathrm{s})$.

\section{Synthesis of [Cu}

The complex was obtained by mixing solutions in acetonitrile of the HLPu ligand $(0.52 \mathrm{~g}, 1.0 \mathrm{mmol}$, in $25 \mathrm{~mL})$ and $\mathrm{CuCl}_{2} \cdot 2 \mathrm{H}_{2} \mathrm{O}(0.17 \mathrm{~g}, 1.0 \mathrm{mmol}$, in $15 \mathrm{~mL})$, while stirring, at $25^{\circ} \mathrm{C}$ for $15 \mathrm{~min}$. In the next step, drops of hydrochloric acid 2.0 M were added until a change from green to light blue color and precipitation of a blue solid, which was filtered off and washed with cold isopropyl alcohol and diethyl ether. Yield: $0.31 \mathrm{~g}, 52 \%$. Anal. Calcd. for $\mathrm{CuC}_{28} \mathrm{H}_{35} \mathrm{~N}_{9} \mathrm{O}_{3} \mathrm{Cl}$ : C, 52.17; H, 5.47; N, 19.56. Found: C, 51.79; H, 5.32; N, 19.21).

\section{Solution Studies}

In order to establish the most likely structure of the complex in solution, ESI-MS, electronic spectroscopy studies were carried out in ACN or ACN/water solutions. ESI-MS analysis of complex [CuII(LPur)] was performed in a pure ACN solution $(0.5 \mu \mathrm{M})$ (Figure S1, see also S12). A group of peaks with a maximum (100\%) at m/z 286.1 with a $2+$ charge was observed. This signal can be assigned to the system [CuII(LPur)]. A second group of peaks with a maximum $(100 \%)$ at $\mathrm{m} / \mathrm{z} 607.1$ with a $1+$ charge was observed, and was assigned to the system $\left[\mathrm{Cu}^{\mathrm{II}}(\mathrm{LPur})\right]+2 \mathrm{H}_{2} \mathrm{O}$. This adducts formed with some ions and solvent molecules commonly occur in mass spectrometry experiments ${ }^{4}$. The UV-vis absorption spectra of complex [Cu$\left.{ }^{\mathrm{II}}(\mathrm{LPur})\right]$ were investigated in the range of 300-900 nm, using ACN and ACN/water as the solvents (Figure S2). In pure ACN solutions, the complex shows a broad band at $\lambda_{\max }, 678 \mathrm{~nm}\left(\varepsilon, 95 \mathrm{M}^{-1} \mathrm{~cm}^{-1}\right)$, assigned to an inner $\mathrm{d}-\mathrm{d}$ type bands of the metal, for the $\mathrm{Cu}^{\mathrm{II}}$ ion in a $\mathrm{d}^{9}$ system. With successive additions of an aqueous 
solution of $\mathrm{NaOH}$ it was possible to observe the appearance of a second band at $\lambda_{\max }, 476 \mathrm{~nm}\left(\varepsilon, 198 \mathrm{M}^{-1} \mathrm{~cm}^{-1}\right)$ assigned to a ligand-to-metal charge-transfer (LMCT) transition from the $\mathrm{p} \pi$ orbitals of the phenolate to the $\mathrm{d} \pi^{*}$ orbitals of the $\mathrm{Cu}^{\mathrm{II}}$ ion.

\section{DNA cleavage}

For DNA cleavage assays, plasmid pBSK-II (Stratagene, USA) was used. The reactions consisted of 330ng $(\sim 30 \mu \mathrm{M}$ base pair) of plasmid DNA with increasing concentrations of buffered complex 1 in specific solutions - as indicated in the figure legends - for 16 hours at controlled temperature and protected from light. The reactions with complex 1 were buffered with $10 \mathrm{mM} \mathrm{CHES}\left(\mathrm{pH} \mathrm{9.0)}\right.$ at $37^{\circ} \mathrm{C}$. The influence of the $\mathrm{pH}$ in the cleavage reactions was assayed at different pH values: 10mM MES (pH 5.5 and 6.0), 10mM HEPES (pH 7.0 and 8.0), and 10mM CHES (pH 9.0). Finally, reactions were stopped with the addition of $5 \mu \mathrm{L}$ of $6 \mathrm{X}$ concentrated running buffer $(0.25 \mathrm{M}$ EDTA, 50\% glycerol and bromophenol blue $0.01 \%$ - $\mathrm{pH} 8.0$ ), and subsequently separated by agarose gel electrophoresis.

\section{Mechanism of DNA cleavage and interaction}

The effect of ionic strength on DNA cleavage was established by adding increasing concentrations of sodium chloride to DNA prior to the treatment with complex 1 . These reactions were conducted in standard conditions $(100 \mu \mathrm{M}$ complex, $16 \mathrm{~h}$ incubation time, $37^{\circ} \mathrm{C}, 10 \mathrm{mM} \mathrm{CHES} \mathrm{pH} \mathrm{9.0)} \mathrm{at} \mathrm{concentrations} \mathrm{of} 100,200,625$, and $1250 \mathrm{mM} \mathrm{NaCl}$. To elucidate the mechanism of DNA cleavage (hydrolytic or oxidative) the reactions described above were prepared with different reactive oxygen species scavengers: $40 \mathrm{mM}$ DMSO, hydroxyl radical scavenger $\left({ }^{\bullet} \mathrm{OH}\right) ; 0.5 \mathrm{mM}$ KI peroxide scavenger; 20U SOD enzyme, scavenger for superoxide anion $\left(\mathrm{O}_{2}{ }^{\bullet-}\right) ; 0.5 \mathrm{mM} \mathrm{NaN}_{3}$, singlet oxygen scavenger. Small molecules may interact with DNA through one or both grooves (minor and major). To determine the preference of complex 1 for each DNA groove, the plasmid was previously treated with groove binding molecules and then added to the cleavage reactions. Netropsin was used as a minor groove binder ${ }^{5}$ and methyl green as a major groove preference binder ${ }^{6}$.

\section{Kinetic Parameters}

In order to estimate the kinetic parameters, reactions were performed as described previously: 330ng DNA in $10 \mathrm{mM}$ CHES (pH 9.0) and different concentrations of complex $1(50,75,100,200,300,500 \mu \mathrm{M})$ for up to $4 \mathrm{~h}$ at $37^{\circ} \mathrm{C}$ and protected from light.

The $k_{o b s}$ value was obtained directly from the slope of the linear regression originated from the plot of the natural logarithm of the amount of the intact form of DNA as a function of reaction time. The plot of $k_{o b s}$ values versus the concentration of the complex follows saturation kinetics (pseudo-Michaelis-Menten kinetics ${ }^{7}$ ).

\section{DNA cleavage under argon atmosphere}

Using the methodology previously described ${ }^{8}$, DNA cleavage reactions were carried out under argon atmosphere in order to evaluate the influence of molecular oxygen in the reactions of the metal complex studied.

\section{Circular Dichroism (CD)}

CD of calf thymus DNA (CT-DNA) was used to assess the interaction of complex 1 with DNA and the potential of structural alterations in the nucleic acid upon binding ${ }^{9}$. CD was performed on a Jasco J-815 spectropolarimeter using $200 \mu \mathrm{M} \mathrm{CT}$-DNA, at $37^{\circ} \mathrm{C}$, assays were done in duplicate, with increasing concentrations of complex $\mathbf{1}$.

\section{High resolution Urea-Polyacrylamide gel electrophoresis}

In order to detect specificity associated to DNA cleavage, a hairpin oligonucleotide (see Fig. S6, S7, S8) was treated with increasing concentrations of complex $1(250,500$, and $750 \mu \mathrm{M})$ for $16 \mathrm{~h}$ at $37^{\circ} \mathrm{C}$, following the methodology previously described ${ }^{10}$, or with the modifications described in the figure legends. 

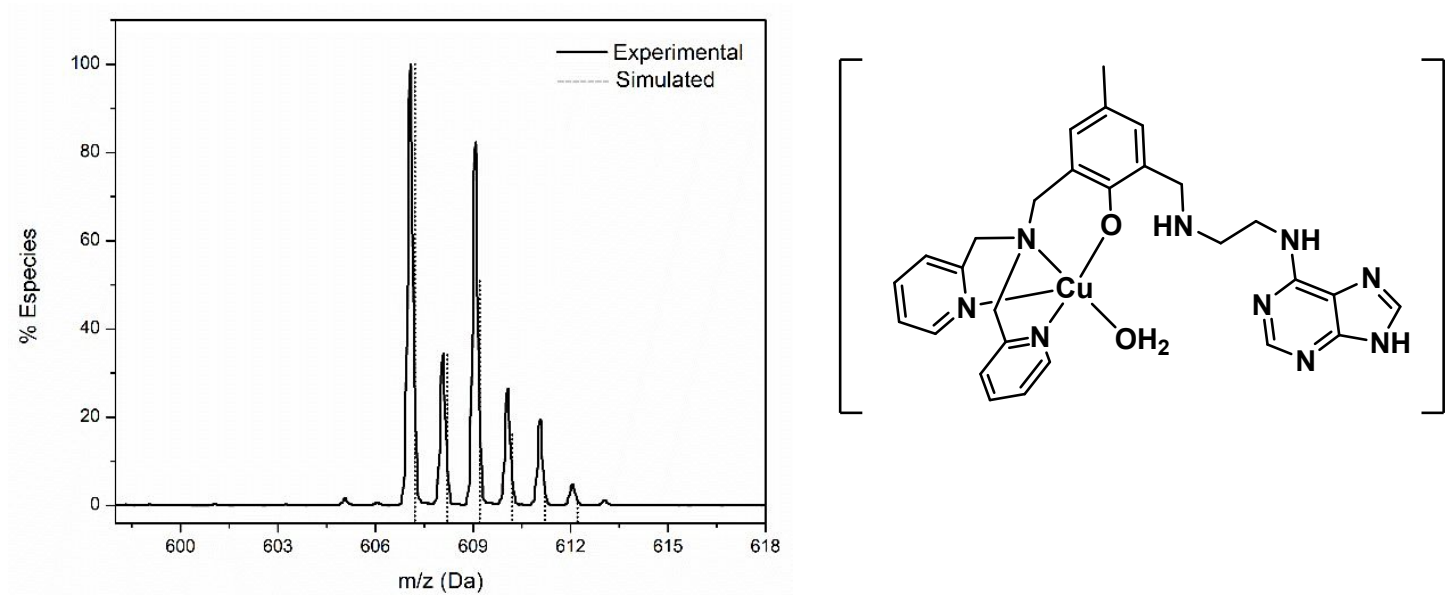

.$\left(\mathrm{OH}_{2}\right)$
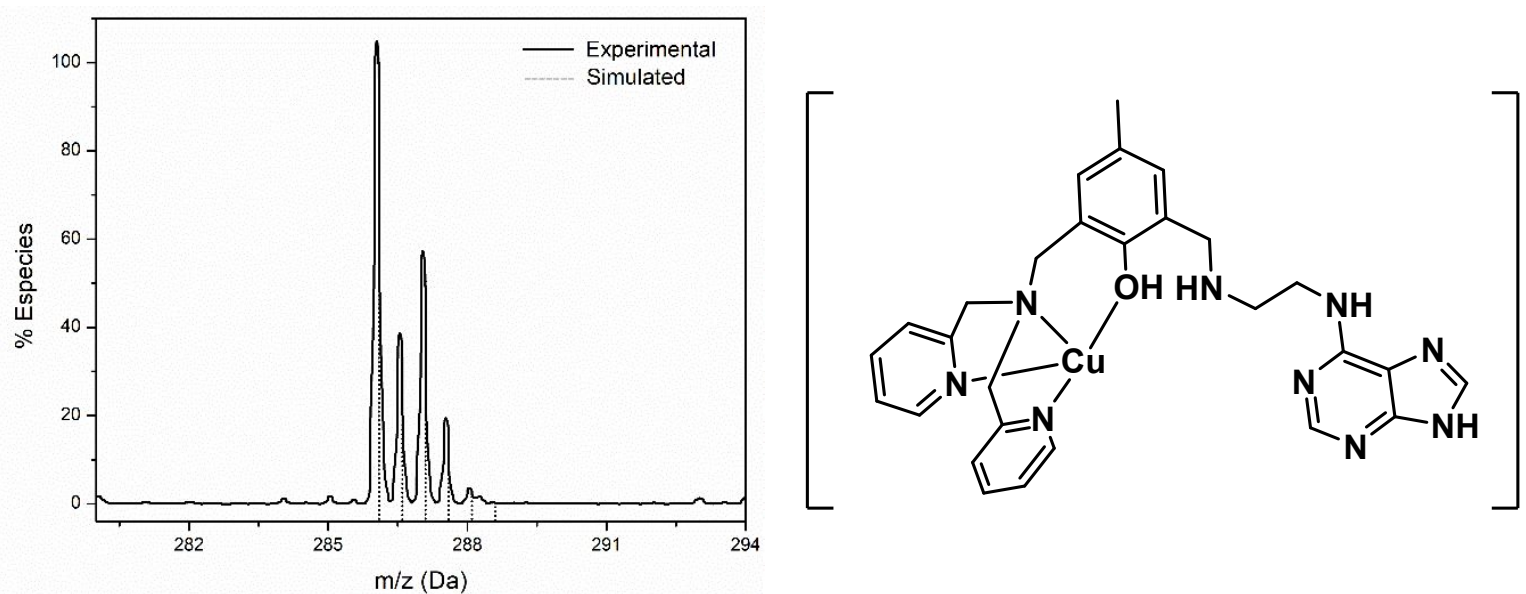

Figure S1. ESI-MS Positive ion spectra in pure acetonitrile for the complex 1 (up) peak (100\%) in 607.1 (1+) for $\mathrm{CuC}_{28} \mathrm{H}_{34} \mathrm{~N}_{9} \mathrm{O}_{3}$ and (down) peak (100\%) in $286.1(2+)$ for $\mathrm{CuC}_{28} \mathrm{H}_{31} \mathrm{~N}_{9} \mathrm{O}$. 


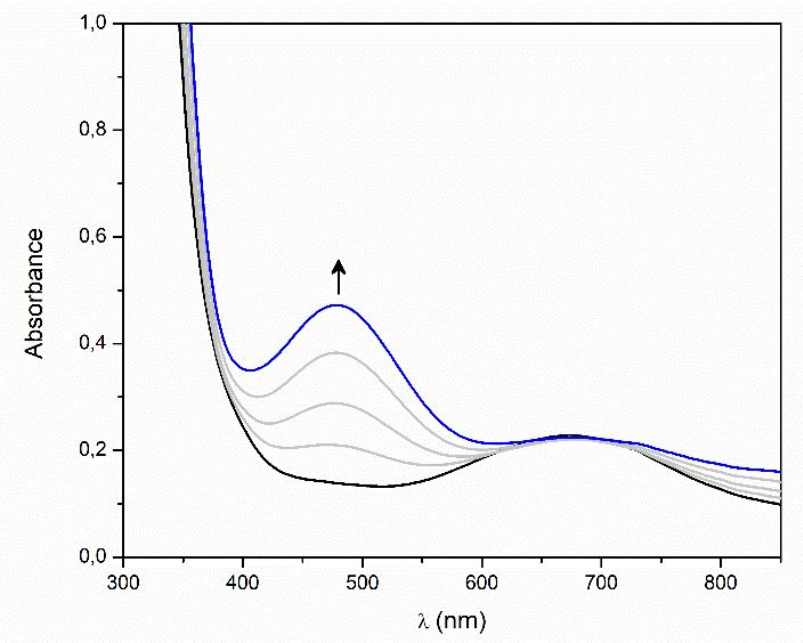

Figure S2. Electronic spectrum of the complex 1 in pure acetonitrile with $\mathrm{NaOH}$ additions (0.25-1 Equivalent). [CuLPu] $=2.5 \mathrm{Mm}$.

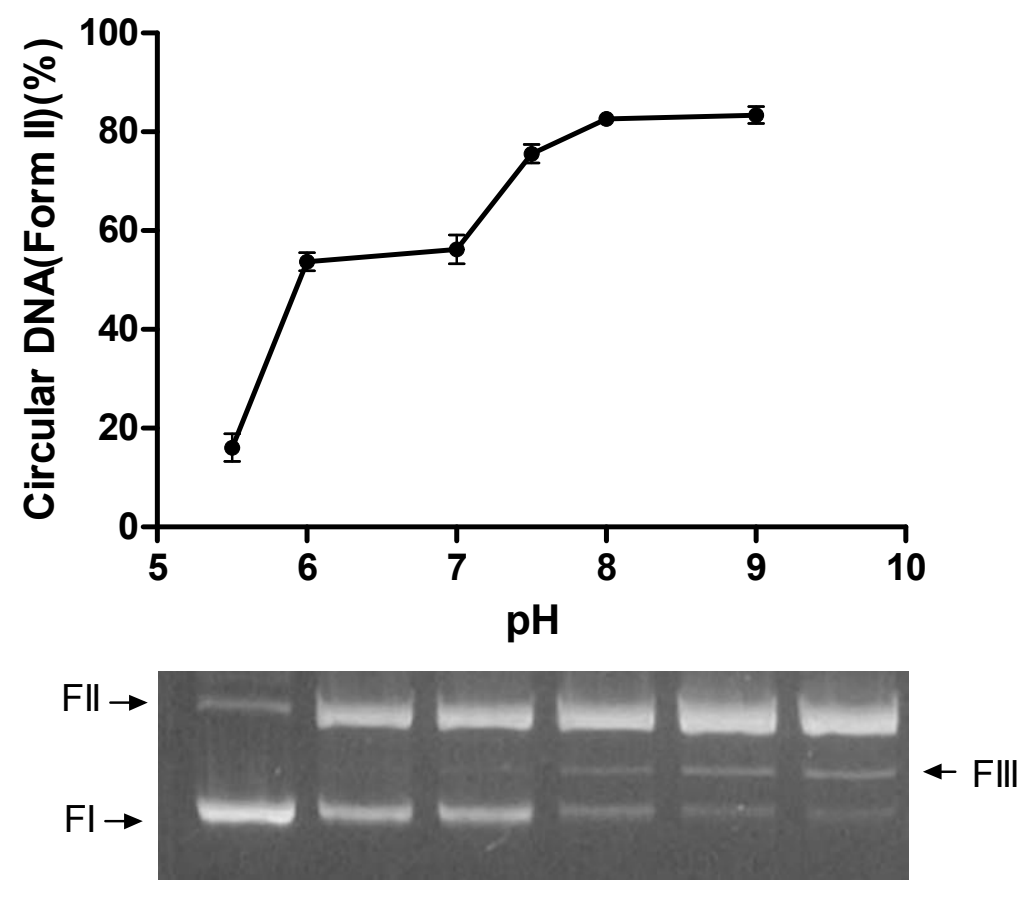

Figure S3: Influence of the reaction $\mathrm{pH}$ for DNA cleavage ([Buffer] $=10 \mathrm{mM}$; MES pH 5.5 and 6.0; HEPES pH 7.0, 7.7 and 8.0, and CHES pH 9.0), (1), $100 \mu \mathrm{M}$ at $37^{\circ} \mathrm{C}$ for $16 \mathrm{~h}$. Representative data from two different experiments expressed as mean $\pm \mathrm{SD}$. 


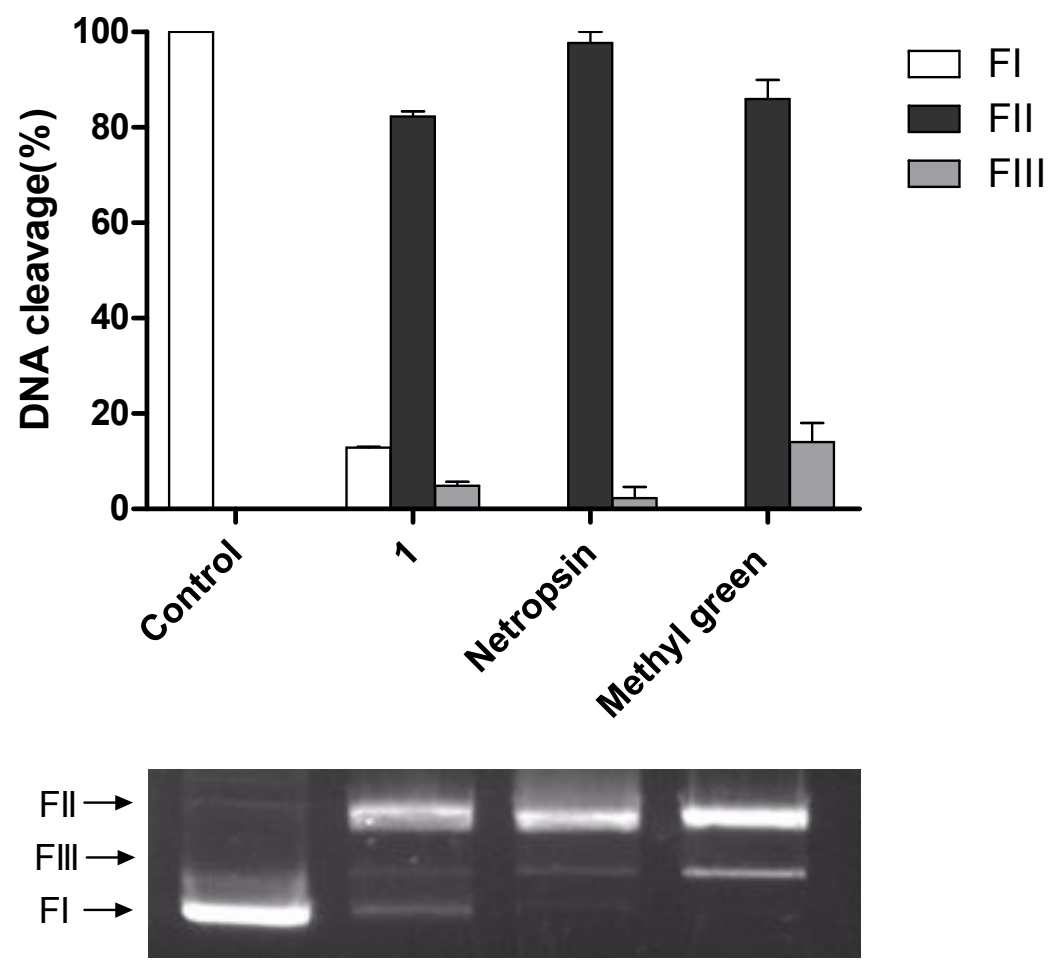

Figure S4: Effect of DNA groove binders netropsin $(50 \mu \mathrm{M})$ and methyl green $(50 \mu \mathrm{M})$ on cleavage of supercoiled DNA by 1 at $100 \mu \mathrm{M}$ for $16 \mathrm{~h}$ at $37^{\circ} \mathrm{C}$ in $10 \mathrm{mM}$ CHES (pH9.0).
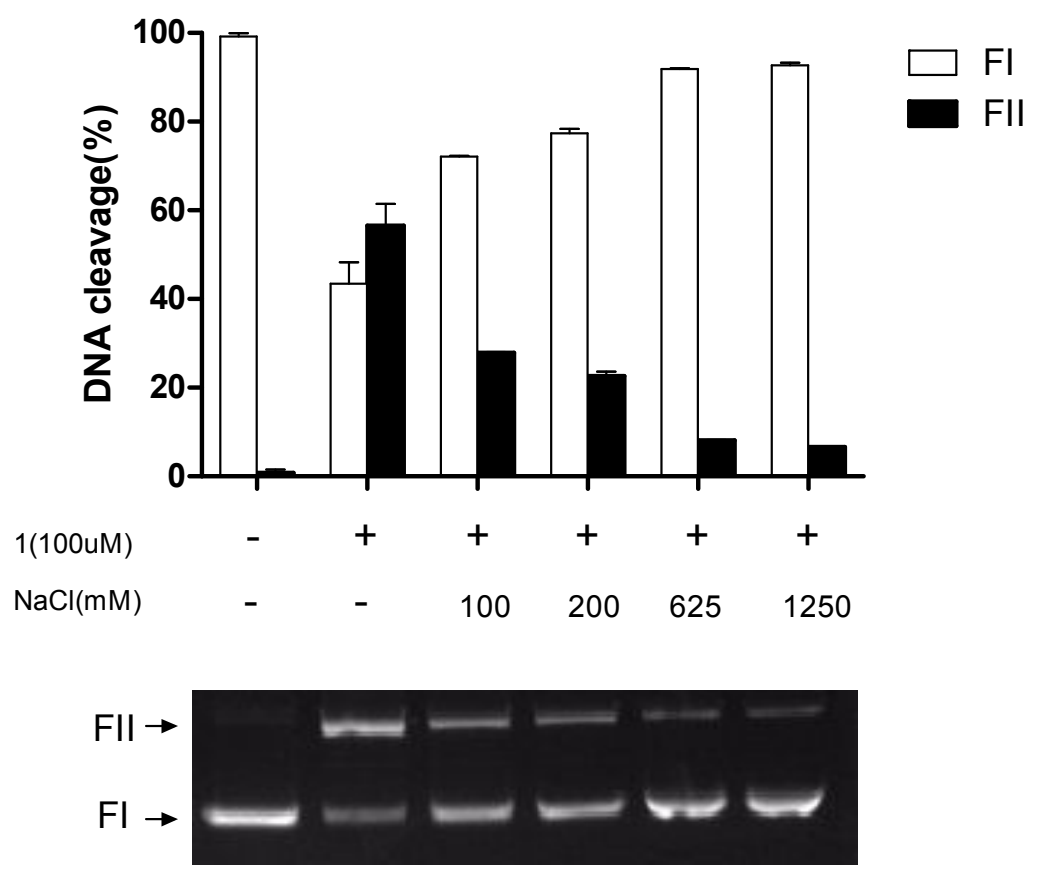

Figure S5: Effect of ionic strength $(\mathrm{NaCl})$ on cleavage of supercoiled DNA by 1 at $100 \mu \mathrm{M}$ for $16 \mathrm{~h}$ at $37^{\circ} \mathrm{C}$ in CHES buffer ( $10 \mathrm{mM}, \mathrm{pH} 9.0)$. Before the addition of the complexes, different concentrations of $\mathrm{NaCl}$ (100 to $1250 \mathrm{mM})$ were added to the reaction media. 


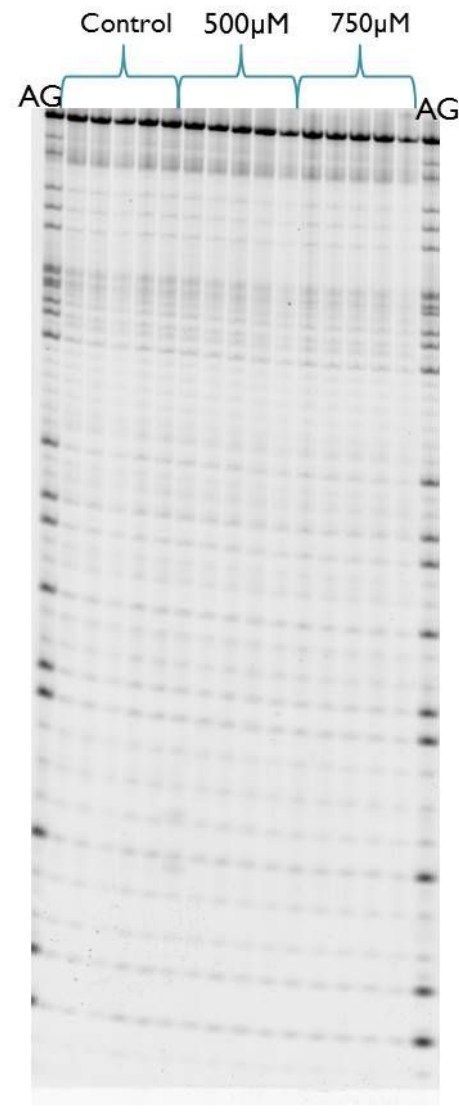

Original complex

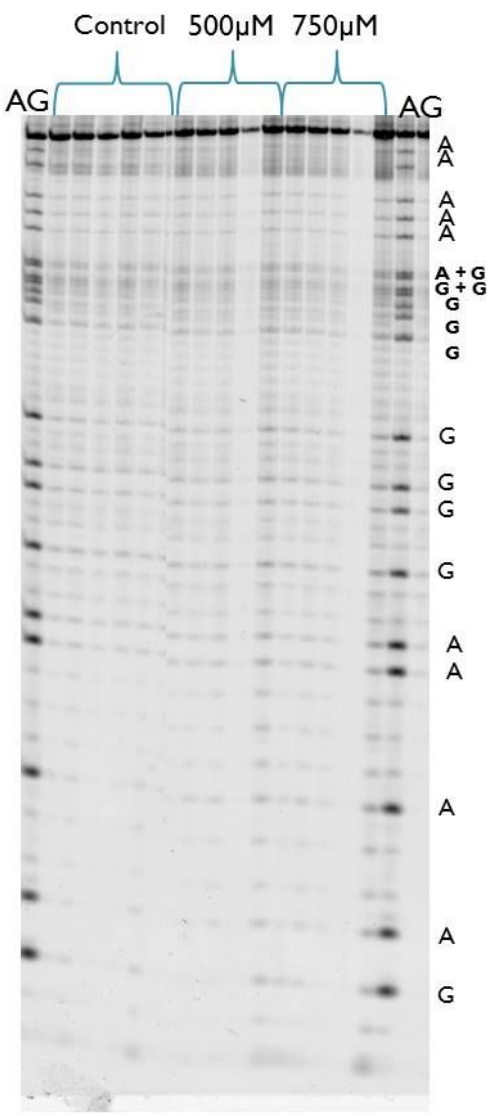

I

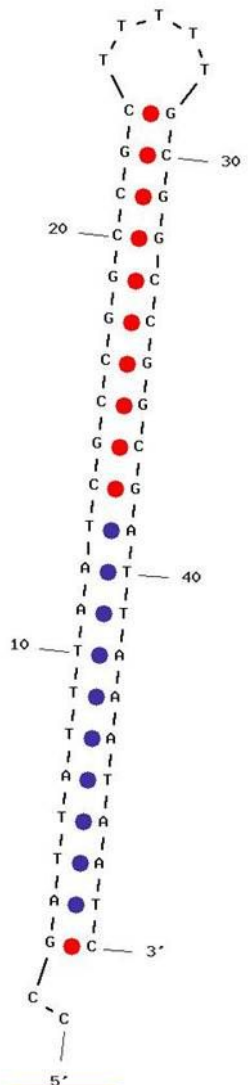

FAM

Figure S6: High resolution gel electrophoresis of the cleavage products of the DNA probe depicted at the right. Complexes ("original complex") (Cu-bpmamff) and 1, at concentrations of 500 and $750 \mu \mathrm{M}$ were incubated for 0 to 24 $\mathrm{h}$ at $37^{\circ} \mathrm{C}$. Cleavage occurs specifically at purine nitrogen bases (A and $\left.\mathrm{G}\right)$, as shown in the figure. "Control" at the left in each panel indicates the reaction in the absence of metal complex. 


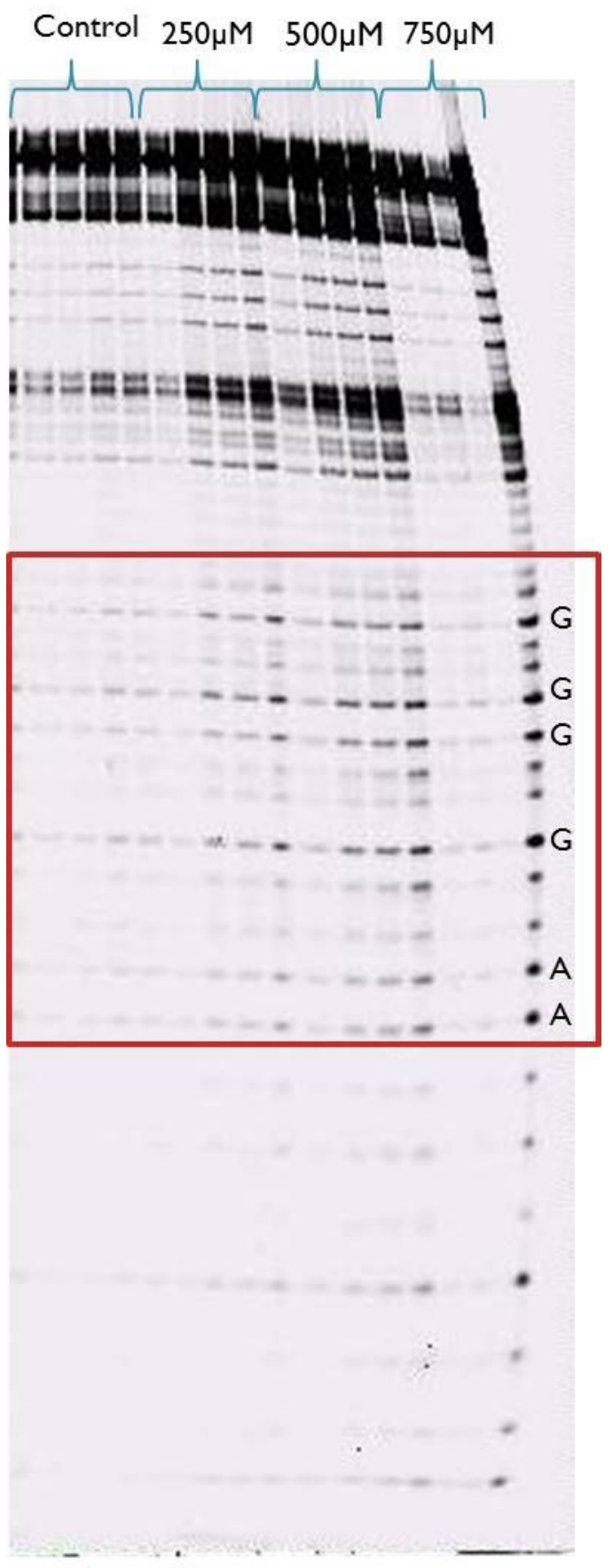

Figure S7: Same as S6, but with the addition of ascorbate $(50 \mu \mathrm{M})$ in the reaction medium - a huge increase in activity is seen. Channels: 1 to 4 - Control - Complex 1 (without ascorbate) - 5 to 8: Complex $1(250 \mu \mathrm{M})+$ Ascorbate $(50 \mu \mathrm{M})$; 9 to 12 - Complex $1(500 \mu \mathrm{M})+$ Ascorbate $(50 \mu \mathrm{M}) ; 13$ to 16 - Complex $1(750 \mu \mathrm{M})+$ Ascorbate $(50 \mu \mathrm{M})$ at different incubation times $0,0.5,1$ and $2 \mathrm{~h}$, and 90 seconds with ascorbate. 


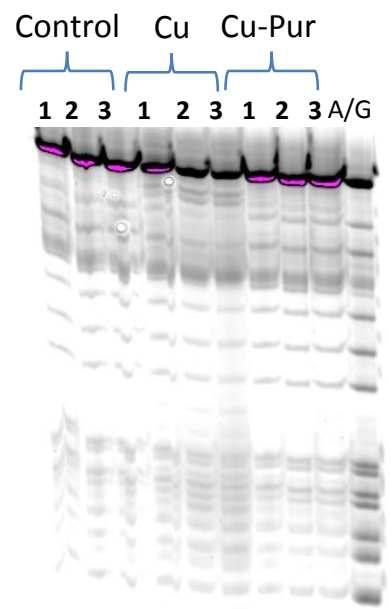

Figure S8. High resolution polyacrilamide electrophoresis of DNA cleavage products obtained from control, Cull complex without ( $\mathrm{Cu}$ ) or with purine moiety (Cu-Pur) at $500 \mu \mathrm{M}$. Incubation in the presence of ascorbate for $\mathbf{0}$ (channel 1), 30 (channel 2) or $90 \mathrm{~min}$ (channel 3). A/G, Maxam Gilbert sequence ladder. Control, no complex; $\mathrm{Cu}$, copper complex without purine moiety; Cu-Pur, copper complex with purine moiety. 


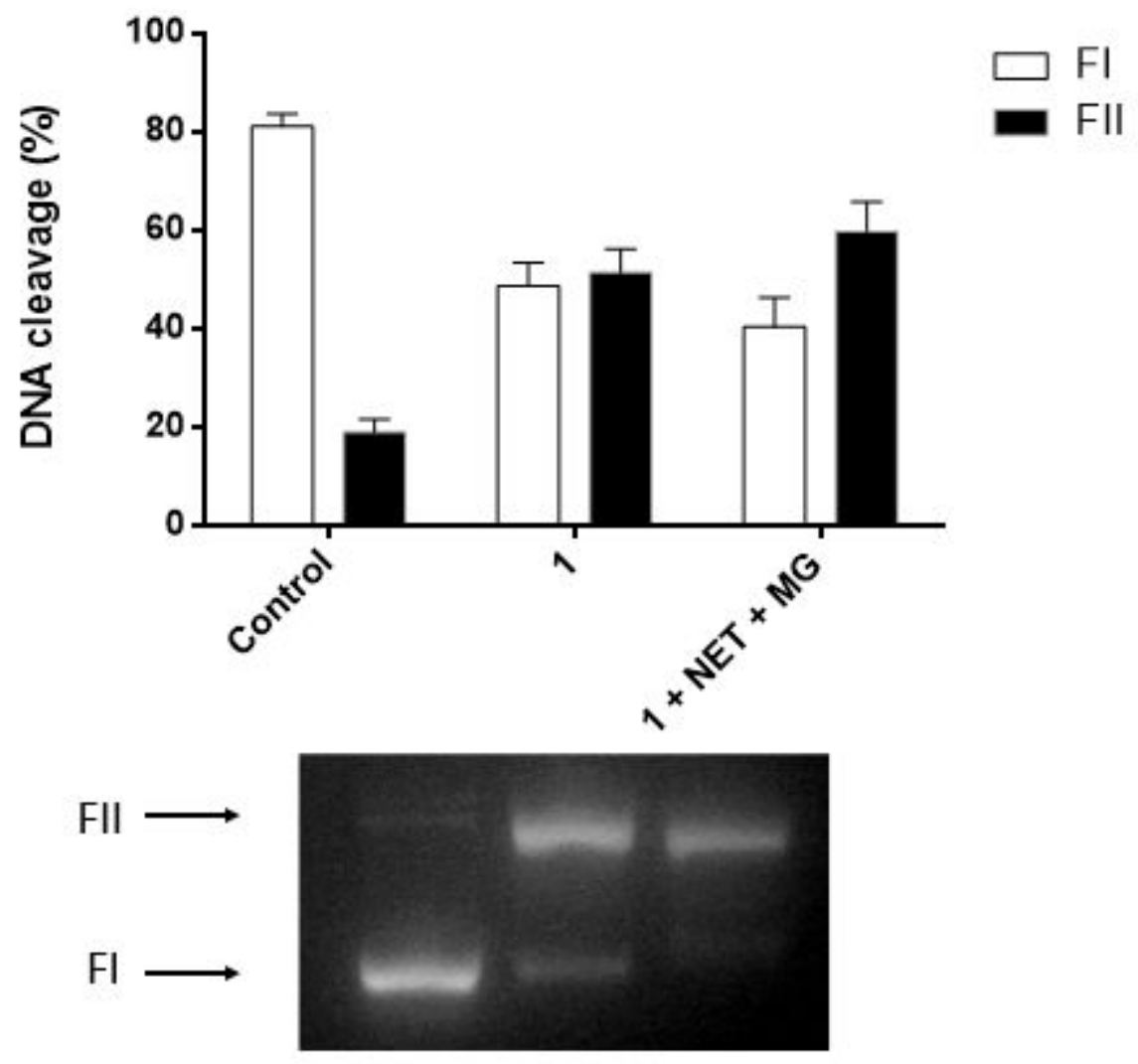

Figure S9. Effect of both DNA groove binders netropsin $(50 \mu \mathrm{M})$ and methyl green $(50 \mu \mathrm{M})$ on cleavage of supercoiled DNA by 1 at $100 \mu \mathrm{M}$ for $16 \mathrm{~h}$ at $37^{\circ} \mathrm{C}$ in $10 \mathrm{mM} \mathrm{CHES} \mathrm{(pH9.0).}$ 
(1)
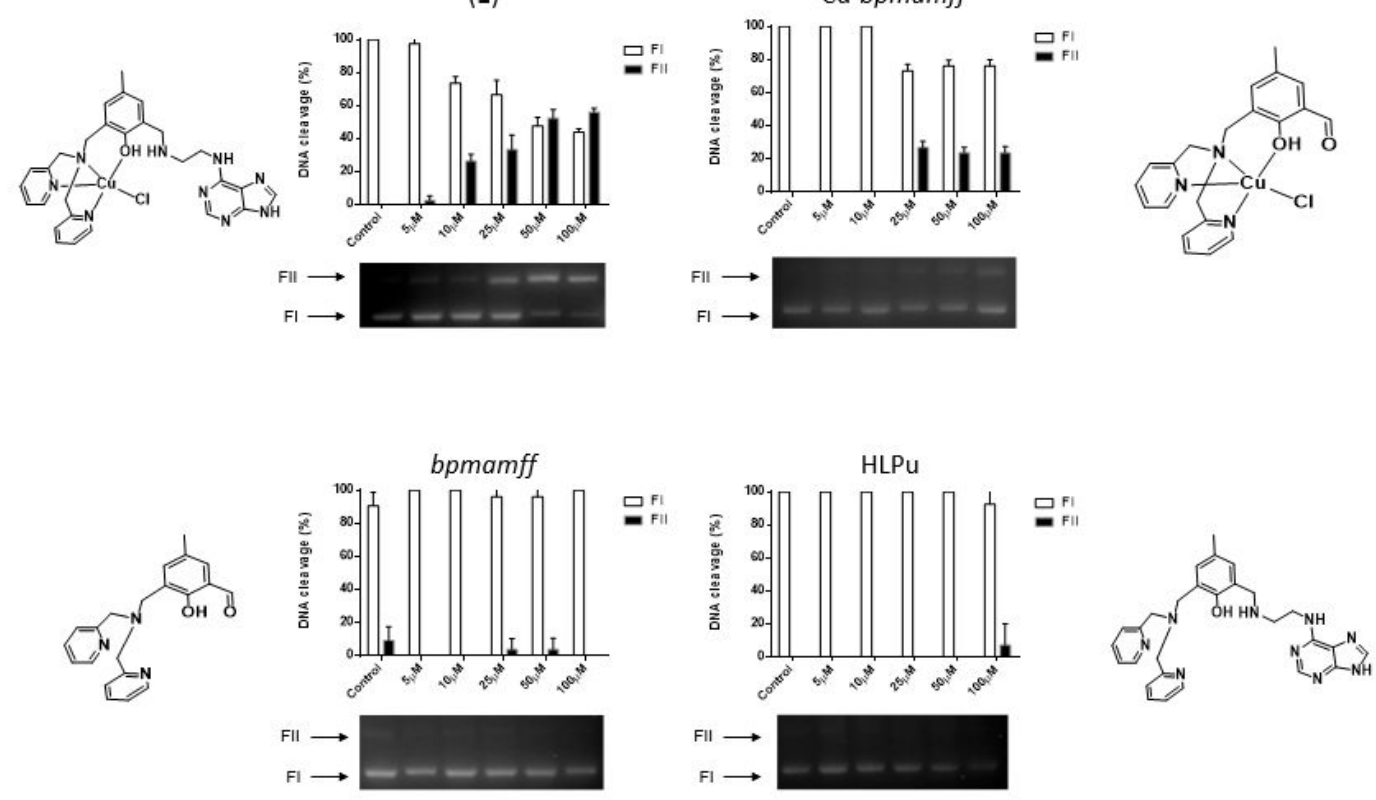

Figure S10 Cleavage of supercoiled DNA by 1 and controls (Cu-bpmaamff, bpmaamff, HLPu) for 16 hours at $37^{\circ} \mathrm{C}$ in CHES buffer (10 mM, pH 9.0) and different concentrations of the complex (5 to $100 \mu \mathrm{M}$ ). Representative data from three different assays expressed as mean \pm SD. 

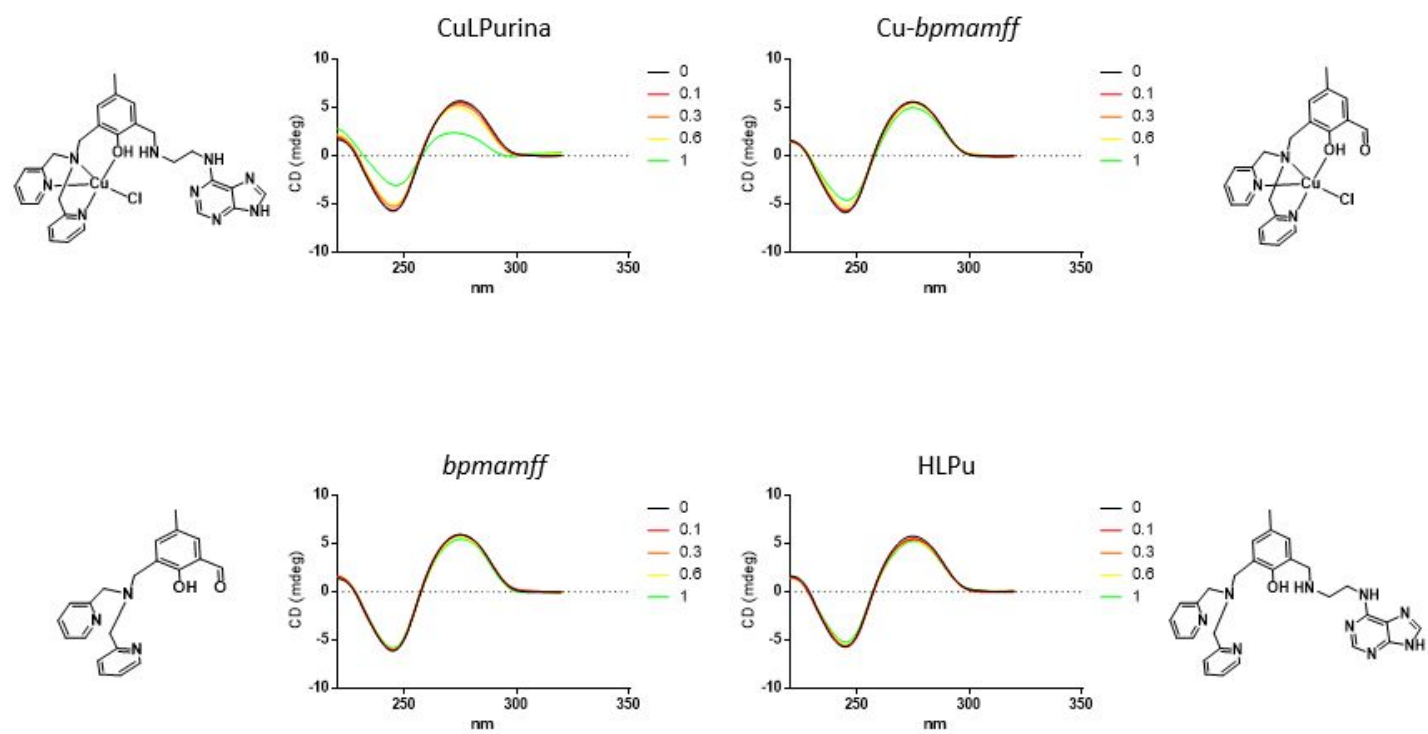

Figure S11 Circular dichroism spectra of CT-DNA $(200 \mu \mathrm{M})$ in the absence or presence of varying concentrations of complex 1 and controls (Cu-bpmaamff, bpmaamff, HLPu) $(r=0.10, r=0.30, r=0.60, r=1.0)$ where $r=[$ complex] $/[C T-D N A]$. 


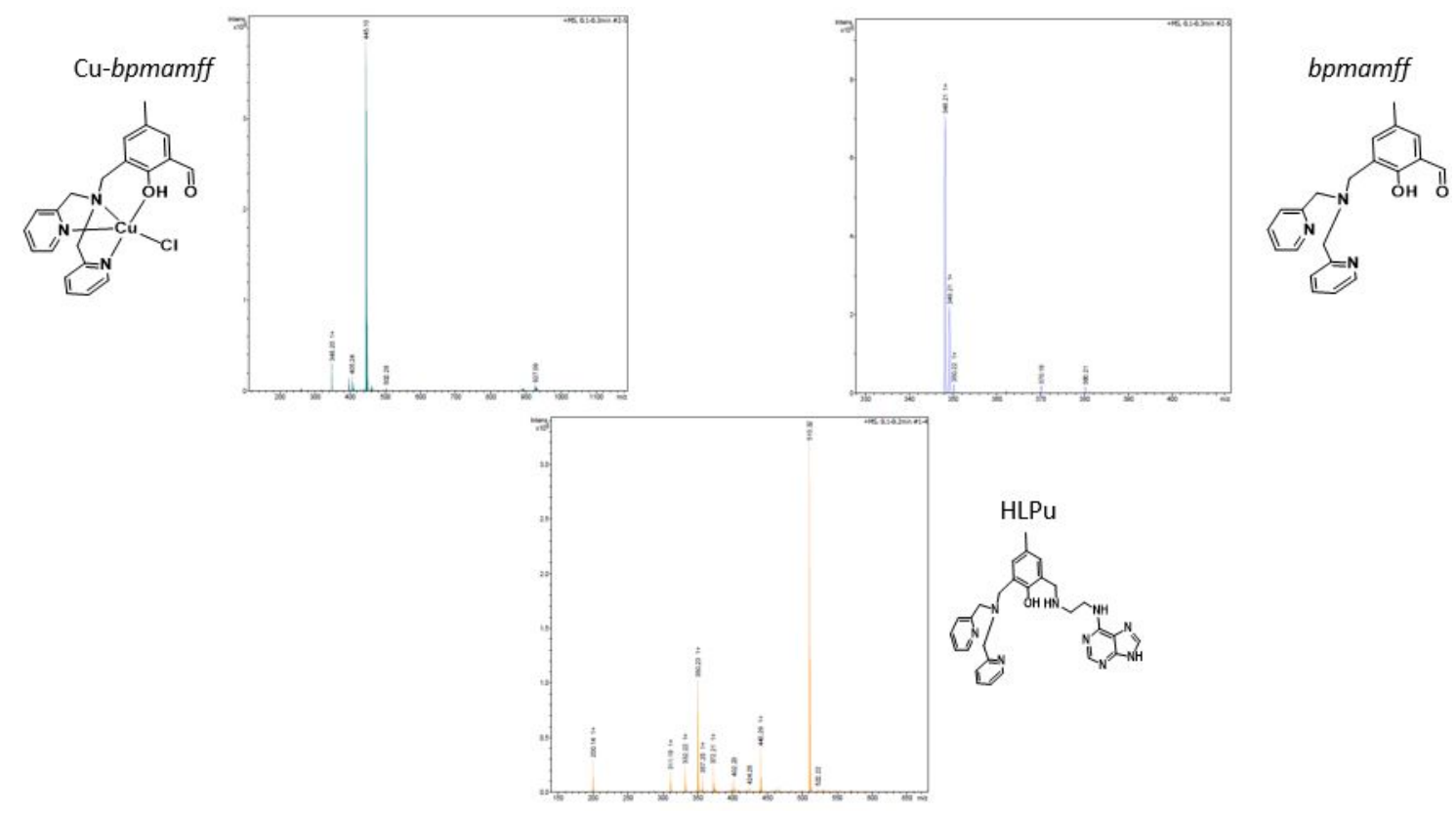

Figure S12. ESI-MS spectra of each ligand and complex described, in addition to those described in Figure S1, under the same conditions.

\section{REFERENCES}

1. Oliveira, M. C. B.; Mazera, D.; Scarpellini, M.; Severino, P. C.; Neves, A.; Terenzi, H., Mononuclear CuII-Phenolate Bioinspired Complex is Catalytically Promiscuous: Phosphodiester and Peptide Amide Bond Cleavage. Inorganic Chemistry 2009, 48 (7), 27112713;

2. Best, M. D.; Brik, A.; Chapman, E.; Lee, L. V.; Cheng, W.-C.; Wong, C.-H., Rapid Discovery of Potent Sulfotransferase Inhibitors by Diversity-Oriented Reaction in Microplates Followed by in situ Screening. ChemBioChem 2004, 5 (6), 811-819.

3. Strohalm, M.; Kavan, D.; Novák, P.; Volný, M.; Havlíček, V., mMass 3: A Cross-Platform Software Environment for Precise Analysis of Mass Spectrometric Data. Analytical Chemistry 2010, 82 (11), 4648-4651.

4. Kruve, A.; Kaupmees, K.; Liigand, J.; Oss, M.; Leito, I., Sodium adduct formation efficiency in ESI source. Journal of Mass Spectrometry 2013, 48 (6), 695-702.

5. Van Dyke, M. W.; Hertzberg, R. P.; Dervan, P. B., Map of distamycin, netropsin, and actinomycin binding sites on heterogeneous DNA: DNA cleavage-inhibition patterns with 
methidiumpropyl-EDTA.Fe(II). Proceedings of the National Academy of Sciences of the United States of America 1982, 79, 5470-5474.

6. Kim, S. K.; Nordén, B., Methyl green: A DNA major-groove binding drug. FEBS Letters 1993, $315(1), 61-64$.

7. Sreedhara, A.; Freed, J. D.; Cowan, J. A., Efficient Inorganic Deoxyribonucleases. Greater than 50-Million-Fold Rate Enhancement in Enzyme-Like DNA Cleavage. Journal of the American Chemical Society 2000, 122, 8814-8824.

8. Scarpellini, M.; Neves, A.; Hörner, R.; Bortoluzzi, A. J.; Szpoganics, B.; Zucco, C.; Nome Silva, R. A.; Drago, V.; Mangrich, A. S.; Ortiz, W. A.; Passos, W. A. C.; de Oliveira, M. C. B.; Terenzi, H., Phosphate Diester Hydrolysis and DNA Damage Promoted by New cisAqua/Hydroxy Copper(II) Complexes Containing Tridentate Imidazole-rich Ligands. Inorganic Chemistry 2003, 42 (25), 8353-8365

9. Chen, L.-M.; Liu, J.; Chen, J.-C.; Shi, S.; Tan, C.-P.; Zheng, K.-C.; Ji, L.-N., Experimental and theoretical studies on the DNA-binding and spectral properties of water-soluble complex $[\mathrm{Ru}(\mathrm{MeIm}) 4(\mathrm{dpq})] 2+$. Journal of Molecular Structure 2008, 881 (1), 156-166.

10. Massoud, S. S.; Perkins, R. S.; Louka, F. R.; Xu, W.; Le Roux, A.; Dutercq, Q.; Fischer, R. C.; Mautner, F. A.; Handa, M.; Hiraoka, Y.; Kreft, G. L.; Bortolotto, T.; Terenzi, H., Efficient hydrolytic cleavage of plasmid DNA by chloro-cobalt(ii) complexes based on sterically hindered pyridyl tripod tetraamine ligands: synthesis, crystal structure and DNA cleavage. Dalton Transactions 2014, 43 (26), 10086-10103. 